\title{
International Evidence on Real Estate Securities as an Inflation Hedge
}

\author{
Crocker H. Liu, New York University \\ David J. Hartzell, University of North Carolina \\ Martin E. Hoesli, University of Geneva
}

\begin{abstract}
The current study investigates whether real estate securities continue to act as a perverse inflation hedge in foreign countries given security design differences. Both a stationary and a nonstationary risk free rate are alternatively used in conjunction with the methodology of Fama and Schwert (1977) and also the methodology of Geske and Roll (1983) to investigate this question. Real estate securities provide a worse hedge against inflation relative to common stocks in some countries and are comparable to stocks in other countries.
\end{abstract} Also, evidence supports the reverse causality model of Geske-Roll.

Most studies that analyze whether real estate investment trusts (REITs) are an inflation hedge have found that REITs act in a perverse manner. ${ }^{1}$ More specifically, returns on REITs appear to be negatively related to the total rate of inflation, as well as both the expected and unexpected components of inflation even though evidence exists that returns on the underlying real estate is positively related to both anticipated and unanticipated inflation. Thus, REITs appear to behave like other common stocks with respect to their inability to hedge against inflation. One recent explanation for this phenomenon which Geske and Roll (1983) advance and which Titman and Warga (1989) test is that stock returns inclusive of REITs are the catalyst to changes in fiscal and monetary policy, which in turn cause an opposite change in the rate of inflation. Under this proposition, a significant positive relationship should exist between current stock returns inclusive of real estate securities such as REITs and future changes in the rate of inflation because these asset returns provide forecasts of changes in inflation.

\footnotetext{
${ }^{1} \mathrm{~A}$ REIT is essentially a closed end investment company whose assets consist of equity and/or debt interests in real estate. Shares in REITs are publicly traded on the major exchanges. The trusts do not pay tax at the corporate level as long as $75 \%$ of the net assets of the trust are invested in "real estate related" assets (e.g., equity investments in real estate, commercial and residential mortgages, and mortgage-backed securities), and as long as $95 \%$ of the net income is distributed to the shareholders.
} 
The current study examines whether real estate securities continue to act as a perverse inflation hedge from a global perspective. In particular, does any type of real estate-related security in a foreign country have the ability to hedge against inflation in that country? Among the countries considered are Australia, France, Japan, South Africa, Switzerland, the U.K. and the U.S. Real estate securities examined include country-specific property trusts and real estate mutual funds which are similar in nature to REITs as well as stocks of real estate operating/development companies. The inflation hedging ability of securitized real estate is compared to that of the stock market in each of these countries. The study also investigates the inflation forecast hypothesis of Geske and Roll (1983) as an alternative explanation for perverse inflation behavior if the international evidence for real estate securities is consistent with that for the U.S. Prior studies have examined the extent to which common stocks in other countries hedge against inflation, but none have analyzed global real estate securities. Further, the design of the real estate security in some countries, such as Switzerland, is such that the return on the real estate security is more representative of the return to the underlying real estate than in other countries. Since evidence exists that the underlying real estate is positively related to both expected and unanticipated inflation. This also suggests that real estate securities in these countries might also hedge against inflation. Consequently, security design might offer an alternative explanation as to why REITs are not an inflation hedge.

With few exceptions, the results for all countries studied are consistent with previous studies. For one, none of the expected inflation proxies dominates across all countries. Secondly, common stocks and real estate either exhibit insignificant relationships with inflation, or act as perverse hedges against both the expected and unexpected components of inflation. Interestingly, however, real estate is a more perverse hedge relative to stocks in some countries. Tests performed using the model of Fama and Schwert (1977) provide insignificant results except for U.S. equity REITs, which demonstrate the wellreported result of negative and insignificant relationships with both expected and unexpected inflation. Tests of the Fisherian Direct Causality Model in Solnik (1983) also provide insignificant results in general. The only exceptions are that for stock indices in all countries except Japan, a perverse relationship is found with unexpected inflation, and hence a perverse hedge against this important component of inflation is indicated. Similarly, U.S. equity REITs exhibit a strong negative relationship with both components of inflation, a finding consistent with the results of the Fama-Schwert tests. Finally, the Geske-Roll proposition is tested and a number of significant relationships are found, supporting the argument that a movement in contemporaneous prices on property trusts and stocks induces a revision of own-country inflationary expectations. Some evidence is found that property trusts in such countries 
as France and Switzerland provide a better signal of movements in inflationary expectations relative to common stocks.

The next section of this article reviews the relevant literature on stock and real estate inflation hedging ability, both in the U.S. and in other countries. A comparison of real estate securities in the various countries follows. Next, the data and methodology are detailed. A discussion of the results is then presented. The final section summarizes the findings and describes areas of research which are suggested by the findings.

\section{Literature Review}

The effectiveness of U.S. stocks to serve as inflation hedges has received considerable attention in the financial literature. Studies include Bodie (1976), Jaffe and Mandelker (1976). Fama and Schwert (1977), and Gültekin (1983b), among others. The general consensus of these studies is that stocks act as a perverse or negative hedge against total inflation as well as both expected and unexpected inflation regardless of the proxy used for expected inflation. Studies such as Firth (1979), Gültekin (1983a) and Solnik (1983) that examine the extent to which common stocks in other countries hedge against inflation also find that the behavior of foreign stocks is consistent with that of U.S. stocks. The only exception to these findings are stocks in the U.K. that offer a complete hedge against inflation.

Consistent with the results for stocks, studies which investigate REITs and other real estate securities have found that these securities, like other stocks which trade on an organized exchange, do not hedge against inflation even though evidence exists that returns on the underlying real estate is positively related to both expected and unexpected inflation. However, conflicting evidence exists on whether REITs hedge against expected inflation. Gyourko and Linneman (1988) find that REITs can provide a hedge against expected inflation but not unexpected inflation. In contrast to this, Park, Mullineaux and Chew (1990) find that equity REITs are significantly negatively related to both expected and unexpected inflation. ${ }^{2}$ Park, et al. also use the semi- annual Livingston survey data as another proxy for expected inflation and find that although a positive tendency exists between REITs and anticipated inflation, the relationship is not significant. However, the REITs still appear to have a significant negative association with unanticipated inflation. Titman and Warga (1989) demonstrate that one reason why REITs act as a perverse hedge is because they are the catalyst to, rather than the response to, changes in

\footnotetext{
${ }^{2}$ The different sign for expected inflation is probably a consequence of the proxies which are used for expected inflation. Gyourko and Linneman (1988) use a within sample ARMA model to forecast inflation, whereas Park, Mullineaux and Chew (IWO) use three-month Treasury bill rates.
} 
the rate of inflation $\{e . g$. , they lead rather than lag inflation). In particular, current returns on equity REITs predict the rate of inflation in the subsequent period.

In contrast to the results for REITs, studies which focus on direct investment in the underlying real estate find that real estate is a good hedge against expected inflation although the evidence is mixed with respect to unanticipated inflation. Fama and Schwert (1977) report that residential real estate offers a positive hedge against both expected and unexpected inflation. In addition to this, Brueggeman, Chen and Thibodeau (1984) find that commercial real estate is also a perfect hedge against expected inflation but does not act as a hedge against unanticipated inflation. On the other hand, Miles and McCue (1982), Hartzell, Hekman and Miles (1987) and Gyourko and Linneman (1988) all find that most income-producing properties exhibit a moderately strong positive relationship with unanticipated inflation in addition to expected inflation. Furthermore, Hartzell, Hekman and Miles (1987) find that real estate continues to exhibit a positive relationship with inflation when individual properties are aggregated by property type, property value and growth of Standard Metropolitan Statistical Area. ${ }^{3}$

\section{Comparison of REITs, Foreign Property Trusts and Property Companies}

The design of real estate securities varies from one country to another. In the U.S., equity REITs are closed-end investment companies which invest the bulk of their wealth in equity real estate. As such, they should constitute a good proxy for U.S. real estate. Several authors, however, have shown that these funds behave more like hybrid assets with investment characteristics of stocks, as well as the underlying real estate. Mengden and Hartzell (1987), for example, show that the price appreciation component of REIT returns move closely with changes in the S\&P500, while the income component is closely related to income as earned from direct investment in equity real estate. This pattern seems, however, to be changing (for example, see Khoo, Hartzell and Hoesli 1993).

In the other countries analyzed, one can categorize property securities in terms of whether they should constitute a good proxy for the underlying real estate. In Switzerland, real estate mutual funds are organized in such a way that unit prices should track the underlying real estate. Unitholders can

\footnotetext{
${ }^{3}$ The recent studies of Giliberto (1988) and Geltner (1989) implicitly raise the possibility that the positive nature of the inflation hedge for real estate found in Miles and McCue (1982), Hartzell, Hekman and Miles (1987) and Gyourko and Linneman (1988) is overstated. These studies employ appraisal based returns. Some critics have argued that appraisers simply incorporate an inflation factor into their appraisals thereby smoothing the return series which in turn biases the results in support of real estate as an inflation hedge. However, Table 3 in Hoag (1980, p. 577) indicates that even when transaction prices are used in lieu of appraisals for commercial real estate, real estate still exhibits a positive correlation (.75) to inflation.
} 
either sell their units on the market (at market price) or can ask the fund management for redemption. The redemption price is based on the appraisals of the properties held by the fund. Market prices cannot lie far below redemption prices because arbitrage opportunities would thus exist. Market prices can, however, lie above redemption prices because the Swiss real estate mutual funds do not issue shares on a continuous basis (semi closed-end funds). Swiss real estate funds invest almost exclusively in property (approximately $96 \%$ of their wealth) and are moderately leveraged (13.9\%). ${ }^{4}$

The situation in the U.K. is different in that some real estate securities should be a good reflection of the real estate market while others are more representative of the stock market. The securitized property vehicles which should best track the underlying real estate are the so-called property unit trusts. These trusts are a special type of authorized exempt unit trust which are commingled vehicles for pension funds and are managed by banks. Prices are quoted on a weekly basis and are based on appraisals of the properties. The leverage is low (approximately $10 \%$ on average) and most companies restrict their investments to U.K. offices, shops and industrial properties. U.K. property unit trusts should thus behave like the underlying real estate. UK property companies, on the contrary, encompass companies investing in real estate and companies which are active in development and construction. Leverage is high (approximately 50\%), and some of the companies in the U.K. property company sample are active outside of the UK. One would expect these latter securities to capture many of the factors affecting common stocks.

In Australia and South Africa, real estate securitization is achieved through property unit trusts. Australian property trusts are closed-end funds (e.g., the number of units on issue does not change except when there are secondary capital offerings or when income is reinvested). These trusts invest in equity real estate ( $84.8 \%$ of total assets on average) and are moderately leveraged $(7.5 \%$ of assets on average). ${ }^{5}$ They are tax neutral (e.g., income and capital gains are passed through to the investor). Unit prices are determined by on-market trading. South African trusts act in very much the same way as Australian funds. Whether or not these funds are a good proxy for the underlying properties will depend on whether investors consider these funds as being more like real estate or more like stocks. This fact has not yet been formally demonstrated. Discussions with analysts in these two countries indicate, however, that Australian property trusts are perceived more like stocks than like real estate, while the contrary holds in South Africa.

\footnotetext{
${ }^{4}$ For more details on Swiss real estate mutual funds, see Hoesli (1993).

${ }^{5}$ Australian law prohibits borrowings in excess of $20 \%$ of gross assets.
} 
In France, real estate securitization is achieved, among other means, through the Societes Immobilieres d'Investissement (SIIs) and the Societes Immobilieres pour le Commerce et I'Industrie (SICOMIs). Slls are funds which invest predominantly (in excess of $75 \%$ ) in residential real estate. Leverage is low and prices are market derived. Rents on residential real estate in France can be adjusted on the basis of the construction cost index. Slls are exempt from corporation tax on rental and related income if at least $85 \%$ of net earnings are distributed to shareholders. ${ }^{6}$ SICOMIs, on the other hand, lease and rent commercial and industrial properties. Prior to 1980, all leasing contracts were automatically adjusted for inflation on the basis of the construction cost index. Since 1980, this has not been the case. The fiscal status of SICOMIs has changed substantially since 1991. Before this date, SICOMIs were exempt from corporate taxes if at least $85 \%$ of net earnings was distributed to shareholders. Since 1991, SICOMIs are progressively being brought to the same system of taxation as other French companies. The full switch will take five years. Leverage is usually much higher than is the case for SIls. It is important to note that more and more SICOMIs are placing weight on equity investment in real estate with cash flow being derived from rents on the underlying properties.

Japanese real estate companies mainly encompass real estate developers. These funds are usually highly leveraged. On average, more than $70 \%$ of their wealth is financed with debt (the most highly leveraged fund is Kakuei Construction with over $90 \%$ of debt and the least leveraged is TOC with less than $40 \%$ in debt). As was the case for U.K. property trust companies, some of the Japanese companies have holdings outside of Japan. ${ }^{7}$ Therefore, one would not expect Japanese real estate companies to be a good proxy for the underlying real estate.

\section{Characteristics of Real Estate-Related Securities and Their Potential as an Inflation Hedge}

Since this study encompasses several different types of real estate-related securities and given that not all are good proxies for the underlying real estate, differences in their structure may affect their expected behavior as an inflation hedge. ${ }^{8}$ Ex ante, those property shares that better reflect the

\footnotetext{
${ }^{6}$ As of 1992, the status of Slls has changed drastically. As a result, most Slls have abandoned their status and have become normal companies. This change, however, occurred after the time period examined here.

${ }^{7}$ No breakdown of investment activity by country is available for all Japanese real estate companies. However, a partial breakdown of investment activity is discussed this study.

${ }^{8}$ For comparison purposes, foreign property trusts or its analog (real estate mutual funds) to the extent possible are used to compare whether these trusts are more effective relative to U.S. REITs in hedging against own-country inflation. If no foreign property trust exists as in the case of Japan, property companies are used. Although property trusts exist in the U.K., the characteristics of these trusts are more similar to U.S. commingled real estate funds. Consequently, the Financial Times property company index is included to see if any differences in the
} 
underlying real estate in a country should provide either a hedge against anticipated and/or unanticipated inflation. This inflation hedging hypothesis should also hold for an appraisal based index such as the U.K. property unit trust index given the prior literature on the hedging effectiveness of alternative U.S. real estate investment vehicles. In contrast, property companies in Japan and the U.K. should act as a perverse hedge against inflation since these companies have characteristics similar to that of other common stocks and prior studies have shown that foreign stocks do not hedge against inflation. Foreign property trusts which are perceived to have more in common with common stocks relative to real estate are also posited to exhibit a perverse hedge against inflation.

\section{Methodology and Data}

\section{Methodology}

Several models are used to examine the relationship between asset returns and inflation from an own-country perspective. First three proxies are examined for expected inflation to see how effective each measure is as a predictor of own country inflation. The three proxies for expected inflation are the lagged return on short term government yields, the Fama and Gibbons (FG) (1982) measure of anticipated inflation, and a proxy for expected inflation generated by an ARIMA $(0,1,1)$ process. ${ }^{9}$ Most previous research uses one of these methods to estimate expected inflation. Short term yields (STY) are used in lieu of rates since the former is ex ante while the latter is an ex post result. The first measure assumes that the expected real yields on short term government securities are not only stationary but also that the government securities market is efficient. In contrast, the FG anticipated inflation measure essentially adjusts for any variation in expected real yields given the evidence in Fama and Gibbons (1984) that the expected real returns on U.S. Treasury bills are not constant over time and might thus represent an inaccurate expected inflation proxy. The final measure of expected inflation comes from using an ARIMA $(0,1,1)$ model based on the prior findings of Gültekin (1983b). A 120 month rolling window is utilized to estimate anticipated inflation for the subsequent month. ${ }^{10}$ The following model is

inflation results are due to appraisals. Thus, this study focuses on two types of foreign property securitiesproperty trusts and property companies.

${ }^{9}$ The Fama and Gibbons measure of anticipated inflation that is used in the current study is

$E\left(\tilde{\Delta}_{t}\right)=F G_{t}=S T Y_{t-1}-(1 / 12) \sum_{s=t-1}^{t-12}\left(S T Y_{s-1}-\log \left(\frac{C P I_{s}}{C P I_{s-1}}\right)\right)$

${ }^{10}$ To estimate expected inflation, the real rate of inflation $(r$,$) is forecasted using a Box-Jenkins model with moving$ average parameters. First, the ex post real rate of return series is generated using the following formula: $r_{i}=S T Y_{i-1}-\tilde{\Delta}_{t}$ where $\mathrm{STY}_{\mathrm{t}-1}$ is the nominal short term yield at time $\mathrm{t}-1$, and $\tilde{\Delta}_{t}$ is the inflation rate in period $\mathrm{t}$. Applying the 
used to ascertain each proxy's effectiveness as a predictor of own country inflation:

$\tilde{\Delta}_{t}=\alpha+\beta E\left(\tilde{\Delta}_{t}\right)+\tilde{\varepsilon}_{t}$

where $\tilde{\Delta}_{t}$ is the inflation rate for a country in month $t, E\left(\tilde{\Delta}_{t}\right)$ is one of the three proxies for anticipated inflation, and $\beta$ should be equal to unity.

Next, real estate and stocks for each country are examined to see if they provide a complete hedge against both anticipated as well as unanticipated inflation in the context of the Fama and Schwert (1977) paradigm. The Fama and Schwert (FS) (1977) model is as follows:

(2) $\tilde{R}_{i t}=\alpha+\beta E\left(\tilde{\Delta}_{t}\right)+\gamma\left[\tilde{\Delta}_{t}-E\left(\tilde{\Delta}_{t}\right)\right]+\tilde{\eta}_{t}$

where $\tilde{\Delta} \mathrm{A}$ and $\mathrm{E}(\tilde{\Delta})$ are the actual and anticipated measures of inflation respectively. Fama and Schwert argue that ex ante, both $\beta$ and $\gamma$ should be positive given financial theory. More specifically, an asset is said to hedge against anticipated (unexpected) inflation when $\beta=1(\gamma=1)$ with a complete hedge against both components of inflation present when $\beta=\gamma=1$. To test this model, each of the three proxies for expected inflation are utilized.

As an alternative to the Fama and Schwert (1977) model, the Fisherian Direct Causality model that Solnik (1983) tested is examined. This model presumes that only real factors influence expected real returns and therefore these returns are independent of both the levels and variations in expected inflation. Empirically, however, nominal asset returns are also used to compare whether the test results arise due to the use of real returns as in Solnik. Mathematically, the regression model is of the form: (3) $\tilde{y}_{i t}=\alpha+\beta_{1} E\left(\tilde{\Delta}_{r}\right)+\beta_{2}\left[E\left(\tilde{\Delta}_{t+1}\right)-E\left(\tilde{\Delta}_{t}\right)\right]+\tilde{\eta}_{t}$

where $r$ is the ex post real return on the asset. $\beta_{1}$ is the coefficient for expected inflation and $\beta_{2}$ represents the coefficient for revisions in anticipated inflation. Both coefficients should equal zero under the null hypothesis that $\beta_{1}=\beta_{2}=0$. The three alternative measures of expected inflation used in estimating the FS model are also used in the present model. A comparison of Equations (1) and (2) with respect to nominal returns reveals that the two models are similar except that the second term on the right hand side of the equation $\left[\tilde{\Delta}_{t}-E(\widetilde{\Delta})\right]$ in (1) is replaced with $\left[E\left(\tilde{\Delta}_{t+1}\right)-E\left(\tilde{\Delta}_{t}\right)\right]$ in (2). The rationale for this is the proposition of Geske and Roll (1983) that the unanticipated inflation term $\left[\widetilde{\Delta}_{t}-\mathrm{E}\left(\widetilde{\Delta}_{t}\right)\right]$ in Fama and Schwert (1977) is really a proxy measured with error for changes in inflation expectations

integrated moving average process and generating forecasts of the expected real return yields a time series resembling a random walk. The anticipated rate of inflation is next calculated as the forecast real rate $\hat{r}$ in period $t$ subtracted from the nominal short term yield in period $\mathrm{t}-1$ or

$\tilde{\Delta}_{t}=S T Y_{t-1}-\hat{r}_{t}$ 
$\left[\mathrm{E}\left(\tilde{\Delta}_{t+1}\right)-E\left(\tilde{\Delta}_{t}\right)\right]$. Consequently, one can regard the regression model that Solnik tested as a modified version of the Fama- Schwert (1977) model.

In addition to the Solnik model, the conjecture of Geske and Roll (1983) is also investigated. Geske and Roll hypothesize that stock returns are the catalyst to changes in fiscal and monetary policy that causes an opposite change in the rate of inflation. Consequently, fluctuations in asset returns act as the stimulus which alters inflation expectations in contrast to the models of Fama and Schwert (1977) and Solnik (1983) which assume that asset returns merely react to anticipated and unanticipated inflation. The reverse causality model of Geske and Roll that the current study tests is of the form (4) $\left[E\left(\tilde{\Delta}_{t+1}\right)-E\left(\tilde{\Delta}_{t}\right)\right]=\alpha+\gamma_{1} E\left(\tilde{\Delta}_{t}\right)+\gamma_{2} \tilde{R}_{t}+\tilde{\eta}_{t}$

where both $\Upsilon_{1}$ and $\Upsilon_{2}$ are expected to be negative e.g., $\Upsilon_{1}<0$ and $\Upsilon_{2}<0 .{ }^{11}$ The coefficient $\Upsilon_{1}$ is the speed of adjustment coefficient for expected inflation. The coefficient $\Upsilon_{2}$ is the product $\Upsilon_{1} * \beta$ where $\beta<0$ represents the marginal signaling impact of stock returns on changes in the expected growth rate of the money supply. The model is tested using the three measures of expected inflation used in testing the FS and Solnik models.

Ordinary least squares (OLS) is used to estimate the parameters in all models examined except in cases when either heteroscedasticity or/and autocorrelation is present. In these instances, the correction of Newey and West (1987) is utilized to correct the standard errors associated with the least squares estimates.

\section{The Data}

Monthly returns on property unit trusts and capital market indices are obtained for Australia, France, Japan, South Africa, Switzerland, U.K. and the U.S. The Interactive Data Corporation (IDC), which is also the source of the CRSP data, furnished the returns on individual property unit trusts in Australia, France and the U.K. The Appendix contains a detailed list of these individual trusts. The return data are adjusted for stock splits in an identical manner to that in the CRSP database. For each of these countries, an equally weighted property trust return series inclusive of dividends is constructed. ${ }^{12}$ For Australia, a

\footnotetext{
${ }^{11}$ The model that Geske and Roll (1983) actually test is nonlinear and of the following form:

$\hat{I}_{t+1}-\hat{I}_{t}=\gamma\left[b R_{t}-\hat{l}_{t}\right]+\varepsilon_{t}$

where $\hat{I}$ represents expected inflation $R$, is the nominal return on an asset over period $t, \gamma>0$, and $\beta<0$. The current study uses the linearized version of their model as in Solnik (1983) since the evidence in Geske and Roll suggests that their results are invariant to whether a nonlinear maximum likelihood or an OLS estimation technique is used. ${ }^{12}$ The total number of shares outstanding for each property trust was not available and therefore a value weighted index could not be constructed.
} 
value weighted Australian property trust index was obtained from the Australian Stock Exchange (ASX). For Japan, returns on property companies are taken from the Nikkei Telecom News Retrieval system which reports Japanese stock price indices by industry for the first section of the Tokyo Stock Exchange. B.O.E. Properties (Transvaal) Limited provided us with a South Africa property unit trust index inclusive of dividends for the Johannesburg Stock Exchange while Bopp ISB AG furnished a value weighted index of Swiss real estate mutual funds. In addition to the IDC return data on property trusts for the UK, returns were obtained on the Financial Times (FT) real estate index which is comprised of property companies (there are no property unit trusts in the FT index). For U.S. real estate, the value weighted monthly index of equity real estate investment trusts (EREITs) inclusive of dividends from the National Association of Real Estate Investment Trusts (NAREIT) is used. ${ }^{13}$

Information on stock market returns, short term government yields and consumer price indices are obtained from the Ibbotson and Associates IDEAS database for each of the seven countries. ${ }^{14}$ The Morgan Stanley Capital International Indices cum dividend is used as the proxy for capital market returns. All monthly return data for each country start in February 1980 and end in March 1991, except for South Africa and Japan which end in June 1990 and February 1991, respectively, because more recent property trust data for these countries was unavailable. All returns are denominated in owncountry currency.

\section{Representativeness of Real Estate-Related Securities}

Since some foreign property companies included in the indices have some U.S. holdings, a question arises concerning the representativeness of the securitized real estate universe of each country (e.g., possibly reducing their hedge against own-country inflation). From the limited published information obtained along with telephone interviews with foreign investment bankers, it appears that the various securitized property indices tire representative of the universe of property stocks that trade in each country. More specifically, property trusts in Australia, France, South Africa and Switzerland do not hold any foreign assets in their portfolios. In terms of market capitalization, Australia property trusts represent over $70 \%$ of the market capitalization for all securitized Australian real estate. The SIls and Sicomis in France account for approximately $75 \%$ and $30 \%$ of the market capitalization for their

\footnotetext{
${ }^{13}$ An adjustment was made to the NAREIT index since the dividend yield in the NAREIT index is calculated using current price $(t)$ rather than the price at the beginning of the period $(t-1)$.

${ }^{14}$ For Australia, the Producer Price Index taken from the I.M.F. International Financial Statistics is used as the proxy for inflation since the CPI is unavailable cither from Ibbotson or from the IMF book. In addition, the Financial Times (FT) stock index for South Africa was used since no Morgan Stanley Capital International Index exists for this country. The FT index begins in January 1981.
} 
respective property sector. The property trusts for South Africa and Switzerland account for over $80 \%$ of the total market capitalization for all publicly traded real estate securities in the respective countries.

In contrast to the preceding countries, property companies in both Japan and the U.K. do invest overseas. According to information obtained from TOYO KEIZAI, overseas properties comprise approximately $8 \%$ of the portfolio on average for the Japanese real estate companies they follow. The Japanese real estate companies that TOYO KEIZAI follow represent about $87 \%$ of the equity value of companies in the Japanese real estate index. ${ }^{15}$ For U.K. property companies, only about $10 \%$ of their properties in aggregate are located in foreign countries with approximately $1 \%$ in Australia, $3 \%$ in the U.S., 3\% in Canada and 3\% in continental Europe. ${ }^{16}$ The Japan and U.K. Financial Times property company indices account for over $80 \%$ and $97 \%$ of the market capital for all property shares in each respective country.

In summary, the real estate security indices used in the tests account for over $75 \%$ of the market capitalization of property stocks within each country. In addition, all companies focus exclusively on domestic activity except for some of the U.K. and Japanese companies. ${ }^{17}$ Consequently, the issue of whether an exposure of foreign property companies in U.S. real estate dampens the effectiveness of the hedge against foreign inflation is mitigated with the possible exception of Japan.

\section{Results}

\section{Inflationary Expectations Proxies}

The results of the inflation hedging tests are dependent on the model that is used to generate inflationary expectations. Several different ways to measure inflationary expectations have been used in the literature and across the different countries. To test for the effectiveness of expected inflation variables, a regression of the form

\footnotetext{
${ }^{15}$ For the individual Japanese real estate companies, the overseas ratios as reported by TOYO KEIZAI are: Mitsui Real Estate 1.7\%, Mitsubishi Estate 11.7\%, Tokyo Land 0.7\%, Sumitomo 3.0\%, Daikyo 8.9\%, Tokyo Tatemono 0\%, Osaka Building $0 \%$ and Sankei Building $0 \%$. The weights used to construct the aggregate overseas ratio are from Bloomberg Financial Markets.

${ }^{16}$ This information is based on a telephone interview with John Atkins from Philips \& Drew in London.

${ }^{17}$ A review of the literature yielded only two studies which deal with foreign real estate-related securities. Barkham and Geltner (1995) use the FT property shares index (used in this study) in conjunction with the Jones Lang Wooten appraisal based index in the U.K. to investigate if price discovery exists for securitized real estate and whether this price information is instantaneously transmitted to the unsecuritized property market. Asabere, Kleiman and McGowan (1991) use the international real estate equities index that Morgan Stanley publishes in their Capital International Perspectives to examine the performance of international real estate-related securities relative to U.S. REITs. Neither study gives any information concerning the market capitalization or the composition of their index (e.g., the proportion of the properties in the index that are non-domestic).
} 
(5) $\tilde{\Delta}_{t}=\alpha+\beta E\left(\tilde{\Delta}_{t}\right)+\tilde{\varepsilon}_{t}$

is tested, where $\widetilde{\Delta}_{t}$, is the observed monthly inflation rate in each of the countries, and $\mathrm{E}\left(\tilde{\Delta}_{t}\right)$ is the anticipated inflation rate that is estimated in one of the three ways used in this article. ${ }^{18}$ In the tests that follow (see Table 1), the "best" measure of expected inflation is the one which exhibits an alpha coefficient that cannot be statistically distinguished from zero, and a beta coefficient that is close to one. Table 1 shows that none of the expected inflation proxies dominates across all countries. In Australia and France, the ARIMA $(0,1,1)$ process generates a positive and significant beta, with a reasonable $R^{2}$. While the other two methods also generate coefficients of the appropriate sign and direction, the ARIMA process exhibits a higher $R^{2}$. In addition, the alpha coefficients are small but significantly different from zero. In Japan, the U.K. and the U.S., the Fama-Gibbons technique for generating inflationary expectations seems to be the most effective, while in Switzerland, short-term yields predict inflation better than the other two techniques. The results in South Africa indicate that none of the proxies have good predictive power, so that results for this country are difficult to interpret. This is not surprising given the influence of the South African government in regulating the short term yield. ${ }^{19}$ In the tests for inflation hedging effectiveness that follow, results will be discussed only for the "best" inflation expectations estimate, although in general, results are consistent across all expectations proxies.

\section{Tests of Inflation-Hedging Ability: Fama-Schwert and Fisherian Direct Causality}

The results of tests for inflation-hedging effectiveness for real estate stocks are generally consistent with the results from studies of broader stock market measures. Results from the FamaSchwert tests of nominal returns on expected and unexpected inflation are shown in Table 2. The results using the "best" expectations proxies in each of the countries generally show weak relationships between nominal real estate stock returns, and either expected or unexpected inflation. In most cases, estimated coefficients are negative, but not significantly different from zero at reasonable levels of confidence. For example, of the seven countries tested, the relationship is negative and significant only for the U.S. The conclusion from the results in Table I is that there does not seem to be a systematic "causal economic relationship" between either inflationary expectations and real estate stock prices, or

\footnotetext{
${ }^{18}$ As discussed in the methodology section, three techniques are used to generate an inflationary expectation proxy: (I) using short term government yields; (2) using the Fama and Gibbons measure (see footnote 4); and 3) using an ARIMA $(0,1,1)$ process.

${ }^{19}$ The authors thank lan Giddy of New York University on this matter.
} 
revisions in inflationary expectations and stock prices, except in the U.S. These results are also found when broad stock market performance measures are used.

Table 1 - Predictors of monthly inflation.

\begin{tabular}{|c|c|c|c|c|c|}
\hline Country/Measure of $E\left(\tilde{\Delta}_{1}\right)$ & $\alpha^{a}$ & $t$-Stat & $\beta^{a}$ & $t$-Stat & $R^{2}$ \\
\hline \multicolumn{6}{|l|}{ Australia } \\
\hline Short Term Yield & 0.4 & 2.1 & 13.6 & 0.8 & $0.01^{b}$ \\
\hline Fama-Gibbons STY & 0.4 & 4.5 & 44.1 & 1.9 & 0.05 \\
\hline ARIMA $(0,1,1)$ & 0.2 & 2.8 & 56.2 & 5.0 & 0.22 \\
\hline \multicolumn{6}{|l|}{ France } \\
\hline Short Term Yield & -0.5 & -5.4 & 112.2 & 8.3 & 0.50 \\
\hline Fama-Gibbons STY & 0.2 & 4.8 & 129.3 & 12.2 & 0.54 \\
\hline ARIMA $(0,1,1)$ & 0.1 & 4.3 & 77.1 & 23.4 & 0.65 \\
\hline \multicolumn{6}{|l|}{ Japan } \\
\hline Short Term Yield & -0.2 & -1.1 & 71.1 & 4.5 & 0.05 \\
\hline Fama-Gibbons STY & 0.1 & 3.4 & 82.0 & 3.7 & 0.05 \\
\hline ARIMA $(0,1,1)$ & 0.1 & 4.3 & 37.7 & 4.1 & 0.05 \\
\hline \multicolumn{6}{|l|}{ South Africa } \\
\hline Short Term Yield & 1.1 & 8.6 & 0.4 & 0.0 & $0.00^{n}$ \\
\hline Fama-Gibbons STY & 1.2 & 9.3 & -13.8 & -0.6 & $0.00^{\circ}$ \\
\hline ARIMA $(0,1,1)$ & 1.3 & 5.0 & -13.4 & -0.6 & $0.00^{r}$ \\
\hline \multicolumn{6}{|l|}{ Switzerland } \\
\hline Fama-Gibbons STY & 0.2 & 3.0 & 45.2 & 1.2 & 0.03 \\
\hline ARIMA $(0,1,1)$ & 0.2 & 2.8 & 36.6 & 2.3 & 0.03 \\
\hline \multicolumn{6}{|l|}{ United Kingdom } \\
\hline Short Term Yield & -0.6 & -2.3 & 114.8 & 4.6 & 0.13 \\
\hline Fama-Gibbons STY & 0.2 & 3.3 & 122.6 & 5.9 & 0.18 \\
\hline ARIMA $(0,1,1)$ & 0.2 & 4.3 & 55.9 & 6.2 & 0.14 \\
\hline \multicolumn{6}{|l|}{ United States } \\
\hline Short Term Yield & -0.0 & -0.4 & 63.4 & 4.7 & 0.20 \\
\hline Fama-Gibbons STY & 0.2 & 7.7 & 93.5 & 8.1 & 0.34 \\
\hline ARIMA $(0,1,1)$ & 0.1 & 4,4 & 63.8 & 10.0 & 0.40 \\
\hline
\end{tabular}

Table 1 gives OLS estimates with standard errors corrected using the Newey-West procedure for February 1980-March 1991.

$\tilde{\Delta}_{t}=\alpha+\beta E\left(\tilde{\Delta}_{t}\right)+\tilde{\varepsilon}_{t}$

where $\tilde{\Delta}_{t}$ and $E\left(\tilde{\Delta}_{t}\right)$ are the observed and the anticipated monthly inflation rates respectively for a country in month $t$. Three proxies for expected inflation $E\left(\tilde{\Delta}_{\mathrm{r}}\right)$ are used: the lagged return on short term government yields, the Fama and Gibbons (1982) measure of anticipated inflation, and a proxy for expected inflation using an ARIMA $(0,1,1)$ process. A proxy is deemed to be an effective predictor of owncountry inflation if $\beta=1$.

a Values are $\times 100$.

b The equation of the line is not statistically significant from zero at either the $5 \%$ or $10 \%$ level based on $\mathrm{F}_{1+132}$. All other equations of the line are significant at the $5 \%$ level.

"Results shown in bold type are for the "best" expected inflation estimate for that country.

Table 3 shows the results of re-estimating the tests in Table 2 (using nominal returns) when revisions of inflationary expectations $\left[\mathrm{E}\left(\tilde{\Delta}_{t+1}\right)-E\left(\tilde{\Delta}_{t}\right)\right]$ are substituted for the unexpected inflation $\operatorname{proxy}\left[\tilde{\Delta}_{t}-E\left(\tilde{\Delta}_{t}\right)\right]$ given the argument of Geske and Roll (1983) that unanticipated inflation is merely a proxy measured with error for changes in expectations. In the six countries other than South Africa, there is a negative relationship reported between expected inflation and real estate stock returns. For 
Australia, Japan, Switzerland and the U.S, the relationship is negative and significant, while in France and the U.K. the relationship, while negative, is insignificantly different from zero. These results are similar to those reported by Solnik (1983) and others, leading to the conclusion that real estate stocks which trade on public markets in these countries exhibit the same inability to hedge against expected inflation as do common stocks. What is surprising is that even the appraisal-based property unit trust index for the U.K. is a perverse hedge against U.K. inflation in contrast to the previous literature on the inflation hedging ability of U.S. CREFs which they resemble in structure.

For the "best" inflationary expectations proxy, negative and significant relationships are found between nominal returns earned on real estate stocks and changes in inflationary expectations for France, Japan, the U.K. (for property companies) and the U.S. Insignificant, but negative, coefficients are found in Australia and the United Kingdom (for property trusts), with no relationship evident in Switzerland. ${ }^{20}$

When the nominal returns on common stocks are considered, the results are less significant in that coefficients estimated for the inflationary expectations variable are significant only for Japan and the U.S. As in all of the other studies, the relationship is negative. For other countries, insignificant results were obtained. This suggests that real estate stocks are a more perverse hedge against anticipated inflation relative to common stocks in most countries. For changes in expectations, the results are negative and significant for all countries except for Japan and South Africa, indicating a strong and pervasive relationship across the countries in the sample. ${ }^{21}$

\footnotetext{
${ }^{20}$ Given the relatively weak ability of the expected inflation proxies to actually forecast inflation in South Africa, the results of the regression estimation are difficult to interpret. For example, the coefficient on the revisions in the expected inflation variable when using the lag of short term Government yields or the Fama-Gibbons technique is -22.26 and -23.61 , respectively, indicating that as expectations are revised by $1 \%$, real estate stock returns in South Africa decline by approximately $23 \%$. Clearly, these results are overstated, and the cause appears to be measurement error in the expectations estimates.

${ }^{21}$ Again, this is consistent with the findings of Solnik (1983) for stock market returns. He finds a more consistent relationship between nominal returns and expectation changes than between nominal returns and actual levels of expectations. While the estimated magnitudes for $\beta_{2}$ are not as high as those found by Solnik, the strength of the relationship is similar.
} 
Table 2 a Fama-Schwert Test of inflation hedging ability.

\begin{tabular}{|c|c|c|c|c|c|c|c|c|c|c|c|c|c|c|c|}
\hline \multirow[b]{2}{*}{ Country/Asset Type } & \multicolumn{5}{|c|}{$\begin{array}{l}\text { Lag of Short Term } \\
\text { Government Yields }\end{array}$} & \multicolumn{5}{|c|}{$\begin{array}{l}\text { Fama-Gibbons Correction } \\
\text { in ST Yields }\end{array}$} & \multicolumn{5}{|c|}{$\begin{array}{l}\text { ARIMA }(0,1,1) \text { Model of } \\
\text { Expected Inflation }\end{array}$} \\
\hline & $\beta$ & $t$-Stat & $\gamma$ & $t$-Stat & $R^{2}$ & $\beta$ & $t$-Stat & $\gamma$ & $t$-Stat & $R^{2}$ & $\beta$ & $t$-Stat & $\gamma$ & $t$-Stat & $R^{2}$ \\
\hline \multicolumn{16}{|l|}{ Australia } \\
\hline Property Trusts & -0.27 & -0.1 & -1.55 & -1.2 & 0.01 & -0.43 & -0.2 & -1.43 & -1.3 & 0.01 & -1.54 & -1.2 & -1.19 & -1.0 & 0.01 \\
\hline ASX Property Trusts & -0.01 & -0.0 & -0.94 & -1.0 & 0.01 & -0.82 & -0.5 & -0.60 & -0.7 & 0.01 & -1.28 & -1.7 & -0.19 & -0.2 & 0.01 \\
\hline MSCI Stock & 0.53 & 0.2 & -2.32 & -1.6 & 0.03 & 0.52 & 0.2 & -2.02 & -1.5 & 0.02 & -1.06 & -0.6 & -2.21 & -1.4 & 0.02 \\
\hline \multicolumn{16}{|l|}{ France } \\
\hline Property Trusts-SII & 0.55 & 0.3 & -2.64 & -2.1 & 0.02 & -3.17 & -1.7 & 0.43 & 0.3 & 0.02 & -1.17 & -0.9 & -0.53 & -0.4 & 0.01 \\
\hline Property Trusts-Sicomi & 3.99 & 2.9 & -1.35 & -1.0 & 0.05 & 1.54 & 0.9 & 0.39 & 0.3 & 0.01 & 0.91 & 0.9 & 0.66 & 0.5 & 0.01 \\
\hline MSCI Stock & 0.63 & 0.3 & -1.44 & -0.7 & 0.00 & -1.65 & -0.6 & 0.29 & 0.1 & 0.00 & -0.78 & -0.5 & 0.87 & 0.4 & 0.00 \\
\hline \multicolumn{16}{|l|}{ Japan } \\
\hline Property Companies & -2.42 & -0.9 & -0.30 & -0.3 & 0.00 & -5.27 & -1.4 & -0.15 & -0.2 & 0.02 & -1.98 & -1.1 & -0.21 & -0.2 & 0.01 \\
\hline MSCI Stock & -1.78 & -0.6 & -0.85 & -1.0 & 0.01 & -4.81 & -1.6 & -0.66 & -0.8 & 0.02 & -1.39 & -1.1 & -0.83 & -1.0 & 0.01 \\
\hline \multicolumn{16}{|l|}{ South Africa } \\
\hline Property Trusts & 3.33 & 2.1 & 1.58 & 1.5 & 0.03 & 3.01 & 1.2 & 1.54 & 1.6 & 0.02 & 3.34 & 1.7 & 1.54 & 1.6 & 0.02 \\
\hline FT Stock & -4.62 & -1.9 & -1.77 & -1.3 & 0.03 & -5.40 & -1.3 & -1.97 & -1.3 & 0.02 & -3.70 & -0.9 & -1.93 & -1.3 & 0.02 \\
\hline \multicolumn{16}{|l|}{ Switzerland } \\
\hline Property Funds & -1.28 & -1.5 & 0.06 & 0.2 & 0.02 & -2.72 & -2.5 & 0.05 & 0.1 & $0.05^{\mathrm{b}}$ & -1.28 & -1.9 & -0.02 & -0.1 & 0.02 \\
\hline MSCI Stock & -2.24 & -0.9 & -0.97 & -0.8 & 0.01 & -2.07 & -0.6 & -1.06 & -0.9 & 0.01 & -1.94 & -0.7 & -1.05 & -0.9 & 0.01 \\
\hline \multicolumn{16}{|l|}{ United Kingdom } \\
\hline Property Trusts & -3.38 & -2.1 & -0.47 & -0.7 & 0.02 & -1.02 & -0.8 & -0.65 & -1.0 & 0.01 & -0.84 & -1.1 & -0.66 & -0.9 & 0.01 \\
\hline FT Property Companies & -1.38 & -0.4 & -0.12 & -0.1 & 0.00 & 0.44 & 0.2 & -0.24 & -0.2 & 0.00 & -0.39 & -0.2 & -0.02 & -0.2 & 0.00 \\
\hline MSCI Stock & 0.40 & 0.2 & -0.49 & -0.6 & 0.00 & 0.76 & 0.3 & -0.49 & -0.5 & 0.00 & -0.02 & -0.0 & -0.40 & -0.5 & 0.00 \\
\hline \multicolumn{16}{|l|}{ United States } \\
\hline Equity REITs & -3.36 & -2.4 & -3.48 & -3.3 & $0.09^{\mathrm{a}}$ & -4.42 & $-\mathbf{3 . 0}$ & -2.51 & -2.2 & $0.09^{a}$ & -3.36 & -3.3 & -2.93 & -2.5 & $0.09^{4}$ \\
\hline MSCI Stock & -2.93 & -1.6 & -2.83 & -2.0 & $0.04^{b}$ & -3.14 & -1.6 & -2.66 & -1.8 & $0.04^{b}$ & -2.59 & -1.9 & -3.24 & -2.1 & $0.04^{b}$ \\
\hline
\end{tabular}

Table 2 presents monthly data for February 1980-March 1991 It illustrates proxies for expected inflation. Results shown in bold type are for the "best" expected inflation estimates for that country. The Newey-West procedure is used to correct the standard errors for heteroscedasticity and autocorrelation.

$\hat{R}_{i t}=\alpha+\beta E\left(\tilde{\Delta}_{t}\right)+\gamma\left[\bar{\Delta}_{t}-E\left(\tilde{\Delta}_{t}\right)\right]+\tilde{\eta}_{t}$

where $R$ represents the nominal asset return and $E\left(\tilde{S}_{t}\right)$ and $\tilde{\Delta}_{t}-E\left(\tilde{S}_{t}\right)$ are the expected and the unanticipated monthly inflation rates iespectively for a country in month $t$. Three proxies for expected inflation $E(\tilde{s}$,$) are used: the lagged return on short term government yields,$ the Fama and Gibbons (1982) measure of anticipated inflation and a prox for apected infation using an ARIMA (0.1,1) process. An asset is said to hedge against anticipated (unexpected) inflation when $\beta=1(\gamma=1)$ with a complete hedge against both components of inflation present when $\beta=\gamma=1$.

The equation of the line is statistically significant from zero at the $5 \%$ level based on $\mathrm{F}_{2,11}$.

b The equation of the line is statistically significant from zero at the $10 \%$ level based on $\mathrm{F}_{2,131}$. All other equations of the line are not statistically significant at either the $5 \%$ or $10 \%$ level. 
Table 3 - Test of Fisherian Direct Causality using nominal asset returns and inflationary expectations.

\begin{tabular}{|c|c|c|c|c|c|c|c|c|c|c|c|c|c|c|c|}
\hline \multirow[b]{2}{*}{ Asset Type } & \multicolumn{5}{|c|}{$\begin{array}{l}\text { Lag of Short Term } \\
\text { Government Yields }\end{array}$} & \multicolumn{5}{|c|}{$\begin{array}{l}\text { Fama-Gibbons Correction } \\
\text { in ST Yields }\end{array}$} & \multicolumn{5}{|c|}{$\begin{array}{l}\text { ARIMA }(0,1,1) \text { Model of } \\
\text { Expected Inflation }\end{array}$} \\
\hline & $\beta_{1}$ & $t$-Stats & $\beta_{2}$ & $t$-Stats & $R^{2}$ & $\beta_{1}$ & $t$-Stats & $\beta_{2}$ & $t$-Stats & $R^{2}$ & $\beta_{1}$ & $t$-Stats & $\beta_{2}$ & $t$-Stats & $R^{2}$ \\
\hline \multicolumn{16}{|l|}{ Australia } \\
\hline Property Trusts & -0.48 & -0.2 & -13.71 & -2.7 & 0.05 & -1.54 & -0.6 & -14.47 & -3.1 & 0.06 & -2.14 & -2.0 & -2.11 & -1.0 & $0.02^{\mathrm{a}}$ \\
\hline ASX Property Trusts & -0.54 & -0.3 & -11.74 & -3.2 & 0.07 & -1.98 & -1.2 & -11.76 & -3.3 & 0.08 & -1.97 & -2.8 & -1.45 & -1.1 & $\mathbf{0 . 0 3}^{\mathrm{a}}$ \\
\hline MSCI Stock & 1.11 & 0.4 & -12.73 & -2.0 & 0.04 & 0.47 & 0.2 & -11.37 & -1.9 & $0.03^{\mathrm{s}}$ & -1.07 & -0.6 & -4.12 & -1.8 & $0.02^{a}$ \\
\hline \multicolumn{16}{|l|}{ France } \\
\hline Property Trusts-SII & -0.29 & -0.1 & -20.22 & -2.7 & 0.06 & -3.94 & -2.1 & -16.29 & -2.1 & 0.06 & -1.44 & $-1,2$ & -8.34 & -1.8 & 0.04 \\
\hline Property Trusts-Sicomi & 3.20 & 2.2 & -24.86 & -3.8 & 0.14 & 0.42 & 0.2 & -23.53 & -4.8 & 0.11 & 0.37 & 0.4 & -8.61 & -1.9 & 0.05 \\
\hline MSCI Stock & -0.54 & -0.2 & -39.15 & -3.8 & 0.10 & -3.32 & -1.3 & -35.16 & -3.2 & 0.10 & -1.43 & -1.0 & -11.32 & -2.0 & 0.03 \\
\hline \multicolumn{16}{|l|}{ Japan } \\
\hline Property Companies & -3.08 & -1.1 & -35.61 & -3.0 & 0.04 & -6.92 & -1.8 & -25.75 & -2.4 & 0.04 & -1.96 & -1.3 & -2.25 & -0.3 & $0.01^{\mathrm{a}}$ \\
\hline MSCI Stock & -1.88 & -0.7 & -16.62 & -1.1 & $0.01^{\mathrm{a}}$ & -5.84 & -1.9 & -16.13 & -1.3 & 0.03 & -0.64 & -0.6 & 5.06 & 0.9 & $0.01^{a}$ \\
\hline \multicolumn{16}{|l|}{ South Africa } \\
\hline Property Trusts & 1.25 & 1.3 & -22.26 & -3.4 & 0.06 & 0.01 & 0.0 & -23.61 & -3.4 & 0.06 & 1.15 & 0.6 & -2.74 & -0.6 & $0.01^{a}$ \\
\hline FT Stock & -3.07 & -1.4 & -1.71 & -0.2 & $0.02^{\mathrm{a}}$ & -3.12 & -0.8 & 3.37 & 0.4 & $0.01^{a}$ & -2.59 & -0.7 & -5.39 & -0.9 & $0.01^{\mathrm{a}}$ \\
\hline \multicolumn{16}{|l|}{ Switzerland } \\
\hline Property Funds & -1.28 & -1.9 & -0.02 & -0.1 & $0.02^{\mathrm{a}}$ & -3.28 & -3.1 & -5.67 & -2.2 & 0.09 & -1.60 & -1.9 & -1.87 & -1.2 & $0.03^{\mathrm{a}}$ \\
\hline MSCI Stock & -2.72 & -1.1 & -22.92 & -2.7 & 0.06 & -3.10 & -0.9 & -17.11 & -2.2 & 0.04 & -2.55 & -1.0 & -7.95 & -1.7 & $0.02^{4}$ \\
\hline \multicolumn{16}{|l|}{ United Kingdom } \\
\hline Property Trusts & -3.92 & -2.5 & -8.93 & -1.2 & $0.03^{\mu}$ & -1.45 & -1.0 & -3.13 & -0.5 & $0.00^{4}$ & -0.87 & -1.2 & -3.17 & -0.9 & $0.01^{\mathrm{a}}$ \\
\hline FT Property Companies & -2.71 & -0.8 & -23.37 & -2.1 & 0.04 & -0.84 & -0.3 & -17.16 & -1.8 & $0.03^{\mathrm{a}}$ & 0.13 & 0.3 & -0.12 & -0.2 & $0.00^{\mathrm{a}}$ \\
\hline MSCI Stock & -0.80 & -0.4 & -21.25 & -2.9 & 0.04 & -0.77 & -0.5 & -20.35 & -3.5 & 0.05 & -0.19 & -0.2 & -4.49 & -1.3 & $0.01^{\mathrm{a}}$ \\
\hline \multicolumn{16}{|l|}{ United States } \\
\hline Property Trusts & 2.69 & -1.9 & -5.60 & -1.8 & 0.04 & -4.96 & -3.2 & -5.74 & -2.0 & 0.08 & -2.87 & -3.0 & -5.60 & -2.7 & 0.09 \\
\hline MSCI Stock & -2.67 & -1.5 & 7.33 & -1.9 & 0.03 & -4.04 & -2.0 & -7.17 & -1.9 & 0.04 & -2.10 & -1.7 & -5.98 & $3-2.1$ & 0.04 \\
\hline
\end{tabular}

Table 3 provides proxies for expected inflation. The Newey-West procedure is used to correct the standard errors for heteroscedasticity and autocorrelation. Monthly data is for February 1980-March 1991.

$\tilde{R}_{i t}=\alpha+\beta_{1} E\left(\tilde{\Delta}_{t}\right)+\beta_{2}\left[E\left(\tilde{\Delta}_{i+1}\right)-E\left(\tilde{\Delta}_{t}\right]+\tilde{\eta}_{t}\right.$

where $R$ represents nominal asset returns, $E\left(\tilde{\Delta}_{t}\right)$ is anticipated inflation, $E\left(\tilde{\Delta}_{t+1}\right)-E\left(\tilde{\Delta}_{t}\right)$ represents changes in inflation expectations, $\beta_{1}$ is the coefficient for expected inflation, and $\beta_{2}$ represents the coefficient for revisions in anticipated inflation. Three proxies for expected inflation $F\left(\tilde{\Delta}_{1}\right)$ are used the lagged return on short term government yields, the Fama and Gibbons (1982) measure of anticipated inflation, and a proxy for expected inflation using an ARIMA 61111 nrocess Both coefficients in the regression should equa! zero under the nul! hypothesis that asset returns are independent of both the levels and variations in expected inflation e.g., $\beta_{1}=\beta_{2}=0$. Results shown in bold type are for the "best" expected inflation estimates for that country.

a The equation of the line is not statistically significant from zero at cither the $5 \%$ or $10 \%$ level based on $\mathrm{F}_{2.130}$. All other equations of the line are statistically significant either at the $5 \%$ or the $10 \%$ level

More appropriate tests of Fisherian Direct Causality employ real returns as the regressor in Equation (2), and the results of this estimation are shown in Table 4. In this regression, for Fisherian Direct Causality to hold, the estimated coefficients $\beta_{1}$ and $\beta_{2}$ should equal zero since only real factors should influence expected real returns. Consequently, expected real returns are hypothesized to be independent of inflationary expectations. Clearly from Table 4 this is not the case. In all countries except for South Africa, estimated coefficients on the expected inflation variable are significantly less than zero. Similar results hold for the expectations change variable in all countries except Switzerland and South Africa. While the results are not quite as strong for common stocks, the general conclusion is similar. In most cases, there is a significant and negative relation between asset returns and both expectations of inflation and changes in expectations of inflation. This suggests that real returns are not independent of these two variables which is consistent with the results using nominal returns. The findings in Table 4 thus provide indirect support for the Geske-Roll argument of reverse causality. 
Table 4 - Test of Fisherian Direct Causality using real asset returns.

\begin{tabular}{|c|c|c|c|c|c|c|c|c|c|c|c|c|c|c|c|}
\hline \multirow[b]{2}{*}{ Asset Type } & \multicolumn{5}{|c|}{$\begin{array}{l}\text { Lag of Short Term } \\
\text { Government Yields }\end{array}$} & \multicolumn{5}{|c|}{$\begin{array}{l}\text { Fama-Gibbons Correction } \\
\text { in ST Yields }\end{array}$} & \multicolumn{5}{|c|}{$\begin{array}{l}\text { ARIMA }(0,1,1) \text { Model of } \\
\text { Expected Inflation }\end{array}$} \\
\hline & $\beta_{1}$ & $t$-Stats & $\beta_{2}$ & $t$-Stats & $R^{2}$ & $\beta_{1}$ & $t$-Stats & $\beta_{2}$ & $t$-Stats & $R^{2}$ & $\beta_{1}$ & $t$-Stats & $\boldsymbol{\beta}_{2}$ & $t$-Stats & $R^{2}$ \\
\hline \multicolumn{16}{|l|}{ Australia } \\
\hline Property Trusts & 0.68 & 0.3 & -14.34 & -2.8 & 0.06 & $\because-2.06$ & -0.9 & -15.67 & -3.1 & 0.07 & -2.97 & -2.7 & -3.29 & -1.6 & 0.04 \\
\hline ASX Property Trusts & -0.75 & -0.4 & -12.37 & -3.1 & 0.08 & -2.51 & -1.5 & -12.96 & -3.7 & 0.10 & $-\mathbf{2 . 8 0}$ & -2.7 & -2.63 & -1.9 & 0.06 \\
\hline MSCI Stock & 0.90 & 0.3 & -13.36 & -2.1 & 0.04 & -0.05 & -0.2 & -12.57 & -2.0 & 0.03 & -1.90 & -1.1 & $-\mathbf{5 . 3 0}$ & -2.3 & 0.04 \\
\hline \multicolumn{16}{|l|}{ France } \\
\hline Property Trusts-SII & -1.44 & -0.7 & -21.13 & -2.9 & 0.06 & -5.28 & -2.4 & -17.12 & -2.9 & 0.09 & -2.28 & -1.9 & -10.02 & -2.3 & 0.07 \\
\hline Property Trusts-Sicomi & 2.05 & 1.4 & -25.77 & -3.9 & 0.13 & -0.92 & -0.5 & -24.36 & -5.2 & 0.11 & -0.47 & -0.5 & -10.30 & -2.4 & 0.06 \\
\hline MSCI Stock & -1.69 & -0.7 & -40.07 & -3.9 & 0.11 & -4.66 & -1.8 & -35.99 & -3.3 & 0.11 & -2.27 & -1.6 & -13.01 & -2.4 & 0.05 \\
\hline \multicolumn{16}{|l|}{ Japan } \\
\hline Property Companies & -3.81 & -1.3 & -36.35 & -3.0 & 0.04 & -7.87 & $-\mathbf{2 . 0}$ & -28.81 & -2.7 & 0.05 & -2.39 & -1.5 & -3.38 & -0.4 & $0.02^{a}$ \\
\hline MSCI Stock & 2.60 & -0.9 & -17.36 & -1.2 & $0.02^{s}$ & -6.79 & -2.2 & $-\mathbf{1 9 . 2 0}$ & -1.5 & 0.05 & -1.07 & -1.0 & 3.94 & 0.7 & $0.01^{\circ}$ \\
\hline \multicolumn{16}{|l|}{ South Africa } \\
\hline Property Trusts & 1.29 & 1.3 & $-\mathbf{2 0 . 4 9}$ & -3.0 & 0.05 & 0.14 & 0.1 & -24.02 & -3.3 & 0.06 & 0.75 & 0.4 & -5.53 & -1.2 & $0.02^{\mathrm{a}}$ \\
\hline FT Stock & -3.11 & -1.4 & 0.00 & 0.0 & $0.02^{\circ}$ & -3.02 & -0.8 & 3.05 & 0.3 & $0.01^{\alpha}$ & -2.99 & -0.8 & -8.09 & -1.3 & $0.02^{a}$ \\
\hline \multicolumn{16}{|l|}{ Switzerland } \\
\hline Property Funds & -1.28 & -1.9 & -0.02 & -0.1 & $0.02^{\mathrm{a}}$ & -3.79 & -3.5 & -6.28 & -2.4 & 0.10 & -2.30 & -2.6 & -4.10 & -2.6 & 0.08 \\
\hline MSCI Stock & $-\mathbf{3 . 3 3}$ & -1.3 & -22.68 & -2.6 & 0.06 & -3.61 & -1.1 & -17.73 & -2.2 & 0.04 & -3.25 & -1.2 & -10.18 & -2.1 & 0.04 \\
\hline \multicolumn{16}{|l|}{ United Kingdom } \\
\hline Property Trusts & -5.05 & -3.3 & -8.59 & -1.1 & 0.04 & -2.74 & $-\mathbf{2 . 0}$ & -4.07 & -0.7 & $0.01^{a}$ & -1.59 & -2.2 & -5.14 & -1.5 & $0.03^{a}$ \\
\hline FT Property Companies & -3.88 & -1.2 & -22.89 & -2.1 & 0.04 & -2.04 & -0.7 & -17.67 & -1.9 & $0.03^{\mathrm{a}}$ & -1.44 & -1.0 & -6.05 & -1.5 & $0.02^{\sharp}$ \\
\hline MSCI Stock & -1.93 & -0.9 & -20.91 & -2.9 & 0.04 & -2.05 & -1.3 & -21.30 & -3.6 & 0.05 & -0.92 & -0.7 & -6.46 & -1.8 & $0.03^{a}$ \\
\hline \multicolumn{16}{|l|}{ United States } \\
\hline Property Trusts & -3.39 & -2.2 & -6.25 & -1.4 & 0.06 & -6.03 & -3.9 & -6.60 & -2.3 & 0.11 & -3.65 & -3.8 & -6.83 & -3.3 & 0.14 \\
\hline MSCI Stock & -3.37 & -1.8 & -7.98 & -2.0 & 0.04 & -5.11 & -2.5 & -8.04 & -2.1 & 0.06 & -2.88 & -2.3 & -7.21 & -2.6 & 0.07 \\
\hline
\end{tabular}

Table 4 illustrates proxies for expected inflation. The Newey-West procedure is used to correct the standard errors for heteroscedasticity and autocorrelation. Monthly data is for February 1980-March 1991.

$\tilde{r}_{i t}=\alpha+\beta_{1} E\left(\tilde{\Delta}_{t}\right)+\beta_{2}\left[E\left(\tilde{\Delta}_{t+1}\right)-E\left(\tilde{\Delta}_{t}\right)\right]+\tilde{\eta}_{t}$

where $r$ represents real asset returns, $E\left(\tilde{\Delta}_{t}\right)$ is anticipated inflation, $E\left(\tilde{\Delta}_{t+1}\right)-E\left(\tilde{\Delta}_{t}\right)$ represents changes in inflation expectations, $\beta_{t}$ is the coefficient for expected inflation, and $\beta_{2}$ represents the coefficient for revisions in anticipated inflation. Three proxies for expected inflation $E\left(\tilde{\Delta}_{t}\right)$ are used: the lagged return on short term government yields, the Fama and Gibbons (FG) (1982) measure of anticipated inflation, and a proxy for expected inflation using an ARIMA $(0,1,1)$ process. Both coefficients in the regression should equal zero under the null hypothesis that asset returns are independent of both the levels and variations in expected inflation e.g., $\beta_{1}=\beta_{2}=0$.

Results shown in bold type are for the "best" expected inflation estimates for that country.

a The equation of the line is not statistically significant from zero at either the $5 \%$ or $10 \%$ level based on $F_{2.130}$. All other equations of the line are statistically significant either at the $5 \%$ or the $10 \%$ level.

\section{Tests of Reverse Causality}

The basic hypothesis of the Geske-Roll argument is that changes in stock prices lead to changes in inflationary expectations, and hence, in estimations of Equation (3), negative coefficients should be expected for both the expected inflation $\left(\Upsilon_{1}\right)$ and stock return $\left(\Upsilon_{2}\right)$ variables. The speed of adjustment coefficient for expected inflation $\curlyvee\left(-\curlyvee=\Upsilon_{1}\right)$ in Table 5 for the "best" predictor of inflation in each of the countries analyzed reveals that this coefficient is not only statistically significant but is also small in magnitude as expected for both property trusts and common stocks in general. However, this coefficient is insignificant in Japan and is relatively large in magnitude for Australia and U.S. property trusts and common stocks. This suggests that investors in Australia and the U.S. revise their expected changes in inflation in each period using a larger fraction $\curlyvee$ of expected inflation. Alternatively, a larger portion of 
changes in inflationary expectations is realized in the same time period in the U.S. and Australia relative to other countries.

As hypothesized, the $\Upsilon_{2}$ estimates are negative, significant, and of small magnitude for both property trusts and common stocks in many of the countries, indicating that as asset returns decrease (increase), changes in expected inflation tend to increase (decrease), For common stock returns, the strongest negative relationships are found in Japan, Switzerland, the U.K. and the U.S. In all of these cases, $\Upsilon_{2}$ is significantly different from zero at the $10 \%$ level. Less significant, but still negative, results are obtained in Australia and France. Similar relationships also hold for property trusts.

Table 6 presents another perspective of Table 5 by imputing out the coefficient $\beta$ which measures the marginal signaling impact of stock and property returns on changes in the expected growth rate of money supply $\left(\Upsilon_{2}=\curlyvee \beta<0\right.$ where $\curlyvee>0$ and $\left.\beta<0\right)$. For Australia, Japan, the U.K. (for property companies but not property trusts), and the U.S., there does not appear to be a noticeable difference in the effectiveness of common stocks or property trusts as a signal for changes in inflation given that $\beta$ is similar for the two assets. ${ }^{22}$ However, returns on property trusts appear to provide a "stronger" inflation signal relative to common stock returns for France and Switzerland. This is partly due to the fact that in France, rents for Slls are tied to the construction cost index while rents for SICOMIs are automatically adjusted for the rate of inflation prior to 1980. As stated earlier, International Evidence On Real Estate Securities as an Inflation Hedge 219 Swiss real estate funds by design track closely to appraised values and as such, one would expect that Swiss property funds provide a stronger inflation signal relative to common stocks.

In summary, the preceding tables show that of the three alternative models of inflation-FamaSchwert, Direct Fisher Causality, Geske-Roll reverse causality-the data appear to more closely support the Geske-Roll causality hypothesis.

\footnotetext{
${ }^{22}$ The findings contrast those of Titman and Warga (1989) who find that returns on property trusts provide a stronger signal of changes in expected inflation relative to common stock returns in the U.S.
} 
Table 5 Geske-Roll test of reverse causality between inflationary expectations and asset returns.

\begin{tabular}{|c|c|c|c|c|c|c|c|c|c|c|c|c|c|c|c|}
\hline \multirow[b]{2}{*}{ Asset Type } & \multicolumn{5}{|c|}{$\begin{array}{l}\text { Lag of Short Term } \\
\text { Government Yields }\end{array}$} & \multicolumn{5}{|c|}{$\begin{array}{l}\text { Fama-Gibbons Correction } \\
\text { in ST Yields }\end{array}$} & \multicolumn{5}{|c|}{$\begin{array}{l}\text { ARIMA }(0,1,1) \text { Model of } \\
\text { Expected Inflation }\end{array}$} \\
\hline & $\gamma_{1}$ & $t$-Stats & $\gamma_{2}{ }^{3}$ & $t$-Stats & $R^{2}$ & $\gamma_{1}$ & $t$-Stats & $\gamma_{2}{ }^{a}$ & $t$-Stats & $R^{2}$ & $\gamma_{1}$ & $t$-Stats & $\gamma_{2}{ }^{\mathrm{a}}$ & $t$-Stats & $R^{2}$ \\
\hline \multicolumn{16}{|l|}{ Australia } \\
\hline Property Trusts & -0.11 & -2.9 & -0.4 & -2.6 & 0.11 & -0.11 & -2.6 & -0.4 & -2.2 & 0.11 & -0.27 & -4.5 & -0.4 & -1.2 & 0.13 \\
\hline ASX Property Trusts & -0.11 & -3.0 & -0.6 & -2.0 & 0.13 & -0.12 & -2.6 & -0.7 & -2.1 & 0.13 & -0.27 & -4.6 & -0.6 & -1.1 & 0.13 \\
\hline MSCI Stock & -0.11 & -3.0 & -0.2 & -1.5 & 0.09 & -0.11 & -2.4 & -0.2 & -1.6 & 0.08 & -0.26 & -4.5 & -0.6 & -1.7 & 0.14 \\
\hline \multicolumn{16}{|l|}{ France } \\
\hline Property Trusts-SII & -0.03 & -0.9 & -0.3 & -1.1 & 0.07 & -0.06 & -1.5 & -0.3 & -1.1 & 0.08 & -0.05 & -1.9 & -0.4 & -1.8 & 0.06 \\
\hline Property Trusts-Sicomi & -0.01 & -0.3 & -0.4 & -1.6 & 0.11 & -0.04 & -0.9 & -0.4 & -1.7 & 0.13 & -0.04 & -1.5 & -0.5 & -1.9 & 0.07 \\
\hline MSCI Stock & -0.02 & -1.0 & -0.3 & -1.7 & 0.11 & -0.06 & -1.4 & -0.3 & -1.7 & 0.13 & -0.04 & -1.8 & -0.3 & -1.4 & 0.06 \\
\hline \multicolumn{16}{|l|}{ Japan } \\
\hline Property Companies & -0.02 & -0.8 & -0.1 & -2.4 & 0.04 & -0.05 & -1.2 & -0.1 & -1.9 & 0.05 & -0.05 & -2.0 & -0.0 & -0.4 & 0.04 \\
\hline MSCI Stock & -0.02 & -0.7 & -0.1 & -1.7 & $0.02^{\mathrm{a}}$ & -0.05 & -1.1 & -0.1 & -1.8 & 0.04 & -0.05 & -1.9 & 0.1 & 1.1 & 0.04 \\
\hline \multicolumn{16}{|l|}{ South Africa } \\
\hline Property Trusts & -0.02 & -1.1 & -0.2 & -2.9 & 0.07 & -0.05 & -1.9 & -0.2 & -2.6 & 0.08 & -0.18 & -2.4 & -0.1 & -0.7 & 0.09 \\
\hline FT Stock & -0.03 & -1.3 & -0.0 & -0.2 & $0.03^{\mathrm{b}}$ & -0.05 & -1.8 & 0.0 & 0.4 & $0.03^{\mathrm{b}}$ & -0.19 & -2.3 & -0.1 & -1.1 & 0.10 \\
\hline \multicolumn{16}{|l|}{ Switzerland } \\
\hline Property Funds & -0.05 & -1.9 & -0.8 & $-\mathbf{3 . 0}$ & 0.08 & -0.11 & -3.6 & -0.7 & -3.1 & 0.09 & -0.16 & $6-3.6$ & -0.6 & -1.3 & 0.09 \\
\hline MSCI Stock & -0.04 & -1.7 & -0.2 & -2.7 & 0.07 & -0.10 & -3.6 & -0.2 & -2.7 & 0.09 & -0.15 & $5-3.4$ & -0.3 & -1.6 & 0.09 \\
\hline \multicolumn{16}{|l|}{ United Kingdom } \\
\hline Property Trusts & -0.06 & -2.4 & -0.1 & -1.1 & 0.05 & -0.07 & -2.2 & -0.0 & -0.4 & 0.05 & -0.09 & $9-2.9$ & -0.3 & -1.1 & 0.07 \\
\hline FT Property Companies & -0.06 & -2.3 & -0.2 & -1.8 & 0.07 & -0.07 & -2.2 & -0.2 & -1.7 & 0.07 & -0.08 & $8-2.8$ & -0.3 & -0.2 & 0.06 \\
\hline MSCI Stock & -0.05 & -2.3 & -0.2 & -2.2 & 0.07 & -0.07 & -2.3 & -0.2 & -2.4 & 0.09 & -0.09 & $9-2.9$ & -0.3 & -1.3 & 0.07 \\
\hline \multicolumn{16}{|l|}{ United States } \\
\hline Property Trusts & -0.12 & -2.8 & -0.4 & -2.2 & 0.08 & -0.18 & -3.8 & -0.5 & -2.4 & 0.11 & -0.14 & -3.0 & -0.9 & -2.8 & 0.11 \\
\hline MSCI Stock & -0.11 & -3.0 & -0.4 & -1.8 & 0.08 & -0.16 & -4.2 & -0.4 & -1.9 & 0.10 & -0.12 & -2.9 & -0.6 & -1.8 & 0.10 \\
\hline
\end{tabular}

Table 5 illustrates proxies for expected inflation. The Newey-West procedure is used to correct the standard errors for heteroscedasticity and autocorrelation. Monthly data is for February 1980-March 1991.

$\left[E\left(\tilde{\Delta}_{t+1}\right)-E\left(\bar{\Delta}_{t}\right)\right]=\alpha+\gamma_{1} E\left(\tilde{\Delta}_{t}\right)+\gamma_{2} \tilde{R}_{t}+\tilde{\eta}_{t}$

where $E\left(\tilde{\Delta}_{1+1}\right)-E\left(\tilde{\Delta}_{)}\right)$represents changes in inflation expectations, $E\left(\tilde{\Delta}_{1}\right)$ is anticipated inflation, $R$ represents nominal asset returns, $\gamma_{1}$ is the speed of adjustment coefficient for expected inflation, and $\gamma_{2}$ represents the marginal signaling impact of stock returns on changes in the expected growth rate of the money supply. Thee proxies for expected inflation $E\left(\tilde{\Delta}_{t}\right)$ are used: the lagged return on short term government yields. the Fama and Gibbons (1982) measure of anticipated inflation, and a proxy for cxpected inflation using an ARIMA (0.1.i) process. Both coefficients in the regression should be negative e.g.. $\gamma_{1}<0$ and $\gamma_{2}<0$ if the reverse causality model holds. The reverse causality model hypothesizes that fluctuations in asset returns act as a stimulus which alters inflation expectations. Results shown in bold type are for the "best" expected inflation estimates for that country

The $\gamma_{2}$ value $\times 100$

b The equation of the line is not statistically significant from zero at either the $5 \%$ or $10 \%$ level based on $\mathrm{F}_{2,130}$. All other equations of the line are significant at either the $5 \%$ or $10 \%$ level. 
Table 6 - Geske-Roll imputed beta.

\begin{tabular}{|c|c|c|c|c|c|c|}
\hline & \multicolumn{2}{|c|}{ Lag of STY } & \multicolumn{2}{|c|}{$\begin{array}{l}\text { Fama-Gibbons } \\
\text { STY }\end{array}$} & \multicolumn{2}{|c|}{$\begin{array}{l}\text { ARIMA } \\
(0,1,1)\end{array}$} \\
\hline & $\gamma_{1}$ & $\beta$ & $\gamma_{1}$ & $\beta$ & $\gamma_{1}$ & $\beta$ \\
\hline $\begin{array}{l}\text { Australia } \\
\text { Property Trusts } \\
\text { ASX Property Trusts } \\
\text { MSCI Stock }\end{array}$ & $\begin{array}{l}-0.11 \\
-0.11 \\
-0.11\end{array}$ & $\begin{array}{l}-0.04 \\
-0.06 \\
-0.02\end{array}$ & $\begin{array}{l}-0.11 \\
-0.12 \\
-0.11\end{array}$ & $\begin{array}{l}-0.04 \\
-0.06 \\
-0.02\end{array}$ & $\begin{array}{l}-0.27 \\
-0.27 \\
-0.26\end{array}$ & $\begin{array}{l}-0.02 \\
-0.02 \\
-0.02\end{array}$ \\
\hline $\begin{array}{l}\text { France } \\
\text { Property Trusts-SII } \\
\text { Property Trusts-Sicomi } \\
\text { MSCI Stock }\end{array}$ & $\begin{array}{l}-0.03 \\
-0.01 \\
-0.02\end{array}$ & $\begin{array}{l}-0.12 \\
-0.40 \\
-0.13\end{array}$ & $\begin{array}{l}-0.06 \\
-0.04 \\
-0.06\end{array}$ & $\begin{array}{l}-0.05 \\
-0.09 \\
-0.06\end{array}$ & $\begin{array}{l}-0.05 \\
-0.04 \\
-0.04\end{array}$ & $\begin{array}{l}-0.09 \\
-0.13 \\
-0.07\end{array}$ \\
\hline $\begin{array}{l}\text { Japan } \\
\text { Property Companies } \\
\text { MSCI Stock }\end{array}$ & $\begin{array}{l}-0.02 \\
-0.02\end{array}$ & $\begin{array}{l}-0.04 \\
-0.05\end{array}$ & $\begin{array}{l}-0.05 \\
-0.05\end{array}$ & $\begin{array}{l}-0.02 \\
-0.02\end{array}$ & $\begin{array}{l}-0.05 \\
-0.05\end{array}$ & $\begin{array}{l}0.00 \\
0.02\end{array}$ \\
\hline $\begin{array}{l}\text { South Africa } \\
\text { Property Trusts } \\
\text { FT Stock }\end{array}$ & $\begin{array}{l}-0.02 \\
-0.03\end{array}$ & $\begin{array}{r}-0.11 \\
0.00\end{array}$ & $\begin{array}{r}-0.05 \\
0.05\end{array}$ & $\begin{array}{r}-0.04 \\
0.00\end{array}$ & $\begin{array}{l}-0.18 \\
-0.19\end{array}$ & $\begin{array}{l}-0.01 \\
-0.01\end{array}$ \\
\hline $\begin{array}{l}\text { Switzerland } \\
\text { Property Funds } \\
\text { MSCI Stock }\end{array}$ & $\begin{array}{l}-0.05 \\
-0.04\end{array}$ & $\begin{array}{l}-0.17 \\
-0.05\end{array}$ & $\begin{array}{l}-0.11 \\
-0.10\end{array}$ & $\begin{array}{l}-0.06 \\
-0.02\end{array}$ & $\begin{array}{l}-0.16 \\
-0.15\end{array}$ & $\begin{array}{l}-0.04 \\
-0.02\end{array}$ \\
\hline $\begin{array}{l}\text { United Kingdom } \\
\text { Property Trusts } \\
\text { FT Property Companies } \\
\text { MSCI Stock }\end{array}$ & $\begin{array}{l}-0.06 \\
-0.06 \\
-0.05\end{array}$ & $\begin{array}{l}-0.02 \\
-0.03 \\
-0.04\end{array}$ & $\begin{array}{l}-0.07 \\
-\mathbf{0 . 0 7} \\
-0.07\end{array}$ & $\begin{array}{r}0.00 \\
-0.03 \\
-0.03\end{array}$ & $\begin{array}{l}-0.09 \\
-0.08 \\
-0.09\end{array}$ & $\begin{array}{l}-0.03 \\
-0.04 \\
-0.04\end{array}$ \\
\hline $\begin{array}{l}\text { United States } \\
\text { Property Trusts } \\
\text { MSCI Stock }\end{array}$ & $\begin{array}{l}-0.12 \\
-0.11\end{array}$ & $\begin{array}{l}-0.03 \\
-0.04\end{array}$ & $\begin{array}{l}-0.18 \\
-0.16\end{array}$ & $\begin{array}{l}-0.03 \\
-0.02\end{array}$ & $\begin{array}{l}-0.14 \\
-0.12\end{array}$ & $\begin{array}{l}-0.07 \\
-0.05\end{array}$ \\
\hline
\end{tabular}

Table 6 illustrates proxies for expected inflation. Beta is imputed using the coefficients in Table 5. Monthly data is for February 1980-March 1991.

$\beta=\gamma_{2} /-\gamma_{1}$

where the coefficient $\gamma_{1}$ is the speed of adjustment coefficient for expected inflation. the coefficient $\gamma_{2}=\gamma_{1} * \beta$ and the coefficient $\beta$ measures the marginal signaling impact of stock returns and property returns on changes in the expected growth rate of the money supply. Results shown in bold type are for the "best" expected inflation estimates for that country.

\section{Conclusion}

Research has shown that common stocks act as a perverse hedge against inflation and its expected and unexpected components in most countries. Existing research also shows that U.S. property trusts are also perverse inflation hedges. When the inflation hedging attributes of foreign property trusts is explored, no evidence is found that real estate securities in other countries are better hedges against inflation than common stocks with the possible exception of French SICOMIs, when the short term yield is used as the expected inflation rate. In fact, property trusts are a more perverse hedge relative to common stocks in some countries. The data appear to more closely support the reverse causality model of Geske-Roll than to support the model of Fama-Schwert and the Fisherian Direct Causality model. In terms of the Geske-Roll model, the results suggest that returns on common stocks are comparable to returns on property trusts as predictors of changes in inflationary expectations in 
general. However, returns on property trusts do appear to provide better predictions of future inflation relative to common stock returns for France and Switzerland.

\section{References}

Asabere, P., R. Kleiman and C. McGowan. 1991. The Risk-Return Attributes of International Real Estate Equities. Journal of Real Estate Research 6: 143-152.

Barkham, R. and D. Geltner. 1995. Price Discovery in American and British Property Markets. Real Estate Economics: 23: 21-44.

Bodie, Z. 1976. Common Stocks as a Hedge against Inflation. The Journal of Finance 31: 459-470.

Brueggeman, W.B., A.H. Chen and T.G. Thibodeau. 1984. Real Estate Investment Funds: Performance and Portfolio Considerations. Journal of the American Real Estate and Urban Economics Association 12: 333-354.

Fama, E.F. and M.R. Gibbons. 1982. Inflation, Real Returns and Capital Investment. Journal of Monetary Economics 9: 297-323.

. 1984. A Comparison of Inflation Forecasts. Journal of Monetary Economics 13: 327-348.

Fama, E.F. and G.W. Schwert. 1977. Asset Returns and Inflation. Journal of Financial Economics 5: 115146.

Firth, M. 1979. The Relationship between Stock Market Returns and Rates of Inflation. Journal of Finance 34: 743-749.

Geltner, D. 1989. Estimating Real Estate's Systematic Risk from Aggregate Level Appraisal-Based Returns. Journal of the American Real Estate and Urban Economics Association 17: 463-481.

Geske, R. and R. Roll. 1983. The Fiscal and Monetary Linkage Between Stock Returns and Inflation. Journal of Finance 38: 1-33.

Giliberto, S.M. 1988. A Note on the Use of Appraisal Data in Indexes of Performance Measurement. Journal of the American Real Estate and Urban Economics Association 16: 77-83.

Gültekin, N.B. 1983a. Stock Market Returns and Inflation: Evidence from Other Countries. Journal of Finance 38: 49-65.

-1983b. Stock Market Returns and Inflation Forecasts. Journal of Finance 38: 663-673.

Gyourko, J. and P. Linneman. 1988. Owner-Occupied Homes, Income-Producing Properties, and REITs as Inflation Hedges: Empirical Findings. Journal of Real Estate Finance and Economics 1: 347-372.

Hartzell, D., J. Hekman and M. Miles. 1986. Diversification Categories in Investment Real Estate. Journal of the American Real Estate and Urban Economics Association 14: 230-254. 
1987. Real Estate Returns and Inflation. Journal of the American Real Estate and Urban Economics Association 15: 617-637.

Hoag, J.W. 1980. Towards Indices of Real Estate Value and Return. Journal of Finance 35: 569-580. Hoesli, M. 1993. Investissement Immobiliere et Diversification de Portefeville. Economica: Paris. Jaffe, J.F. and G. Mandelker. 1976. The Fisher 'Effect' for Risky Assets: An Empirical Investigation. Journal of Finance 31: 447-458.

Khoo, T., D. Hartzell and M. Hoesli. 1993. An Investigation of the Change in Real Estate Investment Trust Betas. Journal of the American Real Estate and Urban Economics Association 21: 107-130.

Mengden, A. and D.J. Hartzell. 1987. Real Estate Investment Trusts-Are they Stocks or Real Estate? Stock Research-Real Estate, Salomon Brothers, Inc: New York, NY.

Miles, M. and T. McCue. 1982. Historic Returns and Institutional Real Estate Portfolios. Journal of the American Real Estate and Urban Economics Association 10: 184-199.

Newey, W. and K. West. 1987. A Simple Positive Semi-Definite, Heteroscedasticity and Autocorrelation Consistent Covariance Matrix. Econometrica 55: 703-708.

Park, J., D.J. Mullineaux and I.K. Chew. 1990. Are REITs Inflation Hedges? The Journal of Real Estate Finance and Economics 3: 91-103.

Solnik, B. 1983. The Relation between Stock Prices and Inflationary Expectations: The International Evidence. Journal of Finance 38: 35-48.

Titman, S. and A. Warga. 1989. Stock Returns As Predictors of Interest Rates and Inflation. Journal of Financial and Quantitative Analysis 24: 47-58.

\section{Appendix A}

\section{Composition of Property Unit Trust Indices}

Australia: Schroder Property Trust, Cities of Australia, General Property Trust, National Mutual Property, Stockland Property Trust and Westfield Property Trust.

France: SII-Cofimeg, Cogifi, Foncina, GFII, Sefimeg, Simco and Socim. SIC-Codetel, Immoffice, Locindus and Unibail.

Japan: Mitsui Real Estate Development, Mitsubishi Estate, Tokyo Tatemono, Osaka Building, Sankei Building, Tokyo Land, Kakuei Construction, Daiwa Danchi, Sumitomo Realty and Development, Odakyu Real Estate, Toho Real Estate, Towa Real Estate Development, Taiheiyo Kouhatsu, Daikyo, TOC and Tokyo Rakutenchi. 
South Africa: Apex, Capital, CBD, Cenprop, Higate, Fedfund, Pioneer, Sanland, Stanprop. Sycom and Tamboti Property Trust.

United Kingdom: Bradford Property Trust, Robert Fleming and Company Property Trust, Hanover Property Unit Trust, Lazard Brothers Property Unit Trust, LAMIT Property Fund, Sheafbank Property Trust and Schroder Property Unit Trust. 